\title{
Tourism Development: A Geographical Perspective
}

\author{
Khairil Wahidin Awang (Corresponding Author) \\ Department of Hospitality and Recreation \\ Faculty of Economics and Management, Universiti Putra Malaysia \\ 43400 Serdang, Selangor, Malaysia \\ E-mail: khairil@econ.upm.edu.my, khairilawang@yahoo.com \\ Wan Melissa Wan Hassan \\ Department of Hospitality and Recreation \\ Faculty of Economics and Management, Universiti Putra Malaysia \\ 43400 Serdang, Selangor, Malaysia \\ E-mail: Melissa@econ.upm.edu.my \\ Mohd Salehuddin Mohd Zahari \\ Faculty of Hotel and Tourism Management \\ MARA University of Technology, Malaysia \\ E-mail: mohdsa02@salam.uitm.edu.my
}

\begin{abstract}
This paper represents an effort to conceptualise tourism and development, and their interlinking features, within the broad geographical perspective. It suggests that, as an industry, tourism has evolved along the development path of dominant development theories; Modernisation, Dependency, Neo-liberalism and Alternative development. The findings suggest that, by utilising the frameworks of these development theories, one could analyse and evaluate dynamic tourism processes, a necessity in understanding how tourism works.
\end{abstract}

Keywords: Tourism, Development, Modernisation, Dependency, Neo-liberalism, Alternative

\section{Introduction}

Tourism is the world's largest industry (Scheyvens and Momsen, 2008). As a sector of the economy, tourism is used by many countries to advocate economic development. It is used as a development strategy due to its economic effects such as generating foreign exchange, creating employment and stimulating local economies (Sindiga, 1999). It is suggested here that tourism has evolved, and has continuously progressed along the trajectory path of development theory. On the other hand, the processes that produce these forms of development are susceptible to features generated by the surrounding environment. This includes prominent economic, cultural and political aspects.

\section{Definitions of Tourism}

Tourism has pluralistic meanings (Smith, 1988). Mieczkowski (1981) and Hall and Page (1999) contend that scholars are troubled by the multitude meanings and concepts of tourism. Thus, there is no standard meaning of tourism whereby researchers can have a point of reference. Consequently researchers are spending more time debating typologies and classification rather than exploring the actual content of tourism, leisure or recreation. For example, Pigram (1985) argues that tourism is a component of recreation, while Murphy (1985) counter-argues that. Nonetheless Dan and Cohen (1991) note that there are also scholars who adapt a more ecclectic stance, instead of being tied down by a specific theoretical approach. In this manner researchers adapt their choice of concepts and meanings according to the demands of their work. Smith (1988) argues that researchers, international and national tourism associations, business entities and government agencies give different definitions based on their own perception and interest. Policy-led and 
industry sponsored research work, for example, may ensure an inclination towards industry priorities, while scholars will define tourism from within their own intellectual domain. Jafari $(1977$, p. 6) defines tourism based on an anthropological point of view. "Tourism is the study of man [sic.] away from his usual habitat, of the industry, which responds to his needs, and of the impacts that both he and the industry have on the host's socio-cultural, economic, and physical environments". On the other hand Murphy (1985, cited by Smith, 1988, p. 9) defines tourism as "the sum of ... the travel of non-residents (tourists, including excursionists) to destination areas, as long as their sojourn does not become a permanent residence. It is a combination of recreation and business". Nonetheless, Shaw and Williams (1994) argue that the World Tourism Organisation's (WTO) definition of tourism or tourist is the most commonly used by literature on tourism.

"Any person residing within a country, irrespective of nationality, travelling to a place within this country other than his usual place of residence for a period of not less than 24 hours or one night for a purpose other than the exercise of a remunerated activity in the place visited. The motives for such travel may be (1) leisure (recreation, holidays, health, studies, religion, sports); (2) business, family, mission, meeting" (WTO, 1981, p. 89).

Smith $(1988,1995)$ contends that the WTO's definition gives guidelines on statistical data collection and thus it gives the most agreed point of reference. These guidelines give scholars, governments and institutions a means to not only measure the growth of tourism within their own constructed borders but also a means to compare them on a global level.

\section{Tourism and Development}

Smith (1988) and Britton (1991) argue that much tourism work lacks a theoretical framework, due to the fact that many of the contributors are trained in peripheral fields, and thus are not exposed to the dynamic complex of social and cultural processes, which inundate tourism phenomena. Previous tourism related studies in the literature, which has a significant amount of work revolving around the impacts of tourism, witnessed concepts and theories that were borrowed or adopted mainly from other branches of social sciences, including geography, though, many researchers failed to recognise their origin (Goeldner et al, 2000). For example, concepts and framework from Geography often serve as foundations for the study of tourism, where the dynamic process that underlie a tourism destination could be understood using approaches such as spatial analysis (Pearce, 1995; Johnston, 1997).

On the other hand, Pearce (1979) identifies six major areas of specialisation from the perspective of geographical interest in the study of tourism: the spatial aspects of supply, the spatial aspects of demand, patterns of movement and flows, the impact of tourism, the geography of resorts, and models of tourist space. Erstwhile, Oppermann (1993) and Pearce (1995) suggest that existing geographically-related theories in tourism have grown along two main paradigms: the diffusionist model and the dependency model. Both contain the construction of places and spaces at their heart (Crang, 1997). However, the former addresses tourism as a regional agent of development, and as such, tourism development is diffused from core to peripheral areas. The latter on the other hand, carries the notion of a subjugated peripheral area by its core counterpart. In the context of countries deemed peripheral, such as the world's less developed countries, there is little detailed research undertaken on tourism (Brown and Hall, 2000).

\subsection{Modernisation Theory}

In the context of modernisation theory (Note 1), tourism has been advocated as a development strategy to generate foreign exchange, to increase the balance of payment, increase GDP, attract development capital, increase the transfer of technology, increase employment (Shaw and Williams, 1994) and promote modern western values of life (Mathieson and Wall, 1982). Van Doorn (1979, cited by Pearce, 1989, p. 12) contends that the processes of tourism development could only be elucidated within the context of the development stage of a country. In this sense, Rostow's (1967) argument that there are five stages of economic development was imperative when tourism development was discussed. Elsewhere, Thurot (1973) has suggested that there are three stages of development in relation to the evolution of the airlines routes. However, Miossec (1976) proposes five stages of development, from the original pioneer resort to a fully developed hierarchy and specialised saturation stage when conceptualising tourist space dynamics (Oppermann and Chon, 1997). Modernisation in tourism development also stipulates for the consumption of 'experience' as an end product. Tourists improved their social structural status when they manage to travel and consume these experiences (Wang, 2000) and hence fulfil their ego needs (Maslow, 1987). (Note 2)

Butler (1980) further improvised the evolution of tourism development through his product cycle-based evolution of tourist destination (see figure 1). Butler proposes six stages of development: involvement, exploration, development, consolidation, stagnation and decline or rejuvenation. More recently, Agarwal (2002) has used Butler's work as a template when she contends that many British seaside resorts, which were in the stagnating or declining stage, (Note 3 ) have rejuvenated when for example theme parks were introduced at these resorts. Agarwal argues that endogenous or exogenous forces also play a significant role in a process of destination development. In the context of number of stages 
involved in tourism development study of destination, Oppermann and Chon (1997) argue that there is no unanimous number.

Meanwhile, Myrdal (1957) uses regional economic development theory in tourism studies, to look at the filtering of economic benefits through regional, national and local economies. In parallel, Pearce (1989) argues that tourism has been used as a tool of distributive justice. Similarly, the establishment of the tourist boards for England, Wales, Scotland and Northern Ireland during the late 1960s, which was initially linked to regional economic policy, underpinned the Labour government's orientation towards welfare, which has resulted in a much stronger public intervention (Hughes, 1992). Significant powers of strategic planning were also bestowed on local government at county level in England and Wales, and at regional level in Scotland.

Apart from influencing local authorities, whose new powers in strategic planning were recognised as an important tool in the managing of tourism, the English Tourist Board (ETB) also adopts the thesis of "growth poles to tourism growth points". For example, a grant under Section 4 of the Tourism Act stipulate that the ETB could adapt a confinement of eligible projects to areas within England that were formally designated as development areas. Similarly, Baidal (2003) explores the decentralisation of the state's power in Spain during the late 1970s (post-Franco's authoritarian administration) that paved the way towards regional development policies on tourism. Under the Franco's regime, the foundations for tourism development revolved around macroeconomic objectives that treated tourism as a generator of foreign exchange to rehabilitate the balance of payments, which had been in deficit. But by the 1990s policies on tourism were based on the configuration of a framework of collaboration between regional and local authorities and the central administration (Ibid). Baidal contends that the adoption of the EEC's (Note 4) structural policy principles, (Note 5 ) and becoming the net recipient of financial resources from the European Union's budget, provided the impetus for the creation of new tourism products that entailed the organisation of new emerging spaces (e.g. coastal, urban, rural or mountain). Consequently, the manifestation of microeconomic objectives in favour of past macroeconomic objectives resulted in qualitative changes and expansive tendency in tourism demand that gave rise to a new model of tourism in Spain (Baidal, 2003 and 2004). From a different perspective, Oppermann (1992), through the use of international forms of tourism, explores the use of tourism as a tool for regional development in Malaysia. He found that 'active' travellers who travelled and stayed in many destinations contributed more to regional development while 'passive' travellers tended to reinforce existing spatial disparities. (Note 6) His research also dwells on the issues of dualism in developing countries, where he argues that tourism is least important in Malaysia's peripheral regions while at the same time its political and economical centres have more than the average share in tourism industry.

However, writers such as de Kadt (1979) and Komilis (1994) began to question the use of tourism as a development tool. De Kadt, for example, questions the benefits posed by tourism where the multiplier effects are lower and leakages are higher than had been previously presumed. On the other hand, Komilis specifically argues about the effectiveness of using tourism in regional economic development in peripheral areas. Such issues are underpinned by the relationship between central and peripheral countries.

\subsection{Dependency Theory}

Tourism development in peripheral countries is strongly influenced by events in the core countries. The flow of mass tourists from central to peripheral countries, and the running of hotels and resorts, are subject to various control mechanisms found in the former (Britton, 1989). The roles of tour operators in core countries, one of the most influential tourism suppliers due to their huge financial resources and industrial leverage, (Note 7) for instance, can exert a strong impact on the occupancy rate of hotels and spatial distribution of tourist flow in receiving countries, many of which resemble peripheral areas (Shaw and Williams, 1994). Furthermore, many of the hotels, particularly those of an international class, are owned or managed by Transnational Corporations. However, Din (1990) contends that not all international standard accommodation chains in developing countries belong to developed countries and hence are not controlled by external force. He exemplifies this notion by noting that locals own several of the luxury hotels in Penang, a tourist destination area in Malaysia. At a different level, these relationships posit the notion of underdevelopment of developing countries because of the exploitation by developed countries (Britton, 1989; Harrison, 1995). "Thus, according to dependency theory, tourism is an industry like any other, which is used by the developed countries to perpetuate the dependency of the developing countries. Instead of reducing the existing socio-economic regional disparities within the developing countries, tourism reinforces them through its enclavic structure and its orientation along traditional structures" (Oppermann, 1993, p. 540).

In parallel, Walpole and Goodwin (2000) contend that this peripheral relationship also exists in a local context. Their study of ecotourism in the protected Komodo National Park in Indonesia, illustrates that economic distributional inequalities favoured external operators and urban residents rather than the villagers. Outsiders control most of the accommodation and boating facilities. 


\subsection{Neo-liberalism}

Meanwhile, a chain of global events, including the oil crisis and economic depression that occurred from the mid 1970s to the mid 1980s, has led to an increase in neo-liberalism in tourism development in many developing countries (Desforges, 2000; Milne and Ateljevic, 2001). Desforges (2000) contends that the national government in Peru 'rolled back' its active role when President Alberto Fujimori imposed a drastic cut in state spending on the tourism industry. The state tourist board's budget went down to zero until it could clearly define and justify its role, and the Ministry of Industry, Tourism and Integration and Commerce's number of employees reduced from 2700 to 300, while state owned hotels were privatised and fees were imposed at the state's tourism school.

Such deregulation, privatisation and liberalisation acts, which were partly inspired by the World Bank and IMF through SALPs, have reduced state influence (Milne and Ateljevic, 2001) and at the same time the acts permitted the increased role and importance of the private sector in the tourism industry. Brenner and Theodore (2002) contend that neo-liberalisation has entailed a reorganisation of institutional, political and geographical settings. Nonetheless the decline of the political-economic power of a nation-state in the advent of a crisis of profit in global economy foretells post-Fordism (Harvey, 1990). Fordism is characterised by economies of scale, mass replication, small number of dominant producers, product standardisation, inflexibility and mass marketing to an undifferentiated clientele while its post period is underpinned by more specialised and small scale production.

\subsection{Alternative Development}

The last remaining form of tourism development is alternative tourism. The concept started to surface in the literature some two decades ago (e.g. Dernoi, 1981; Jenkins, 1982). Mowforth and Munt (2003) argue that there is no standard uniform agreed meaning among scholars pertaining to this form of tourism. Butler (1990) suggest that alternative tourism has been associated already with wide ranges of different notions and concepts, and therefore it is impossible to define it explicitly. Nonetheless, the approach has remained focussed on the concept of sustainability (ibid), a concept that can be traced back to the conservation movement in the west during the late $19^{\text {th }}$ century (Hall, 1998). However, in the context of tourism specifics, concepts of alternative tourism encompass a range of tourism strategies that include 'soft', 'responsible', 'green', 'appropriate', 'controlled', 'people friendly', small scale' and 'cottage' characteristics (Conference Report, 1990). The 'green movement', which is associated with the wider concept of the 'green consumer', for example, puts forth the promotion of environmental issues in tourism (Shaw and Williams, 1994). Krippendorf (1986), furthermore, argues for the notion of 'a soft and human tourism', which discourages intolerable social and ecological damage. Environmentally conscious tourists, many of whom are part of the 'inner-directed' lifestyle group whose leisure pursuits are motivated by new experiences, creativity, human relations and personal growth (Gordon, 1991), lead to the demand for environmentally sound holiday. Gordon adds that it is the tourists' influence that forces politicians and tourism businesses alike to consider the environment a genuine concern. Such conditions culminated in ecotourism, a new form of tourism development:

"Travelling to relatively undisturbed or uncontaminated natural areas with the specific objective of studying, admiring, and enjoying the scenery and its wild plants and animals, as well as any existing cultural manifestations (both past and present) found in these areas..." (Ceballos-Lascurain, 1987, cited by Boo, 1990, p. xiv).

While Shaw and Williams (1994) noted a new trend in which tourism businesses such as tour companies have started to reassess their image by offering 'ecological holidays' to potential clients, Mowforth and Munt (2003, p. 80) suggest that “...the term 'sustainability' can be and has been hijacked by many to give moral rectitude and 'green' credentials to tourist activities". Similarly, Ioannides (2001) treat the phenomenon cautiously. Ioannides argues that British-based International Federation of Tour Operators (IFTO) embrace of sustainable tourism is more to do with profit, particularly in an era where tourists are becoming discerning and sophisticated. However, Shaw and Williams (1994, p. 247) argue that "while many tourists will only pay lip-service to 'green holidays', as equally will sections of the tourism systems; but this may not ultimately detract from the importance of green tourism". To this Poon (1994) surmises that in the era of 'new tourism', package tours are fast becoming a thing of the past and tourism has become segmentalised.

In the same vein, Ateljevic and Doorne (2000) argue that small-scale tourism businesses are becoming more important due to the demand of a new hybrid of tourists. The advent of this lifestyle entrepreneur has been a positive stimulus in the growth of small tourism related businesses or tourism entrepreneurship. Ateljevic and Doorne argue that unlike the conventional entrepreneurship of production and consumption, the lifestyle entrepreneur has an underpinning factor in that "business represents an opportunity to indulge in in-depth place experience, which integrates both lifestyle and identity" (Ibid, p. 378). In this sense, lifestyle, rather than economic gain is the main motive behind business operations such as the Black Water Rafting, an enterprise that deals with river 'sledging' activity in New Zealand. Hence 'lifestyle' is one of the diverse reasons on why people indulge in tourism related businesses other then financial rewards. Ateljevic and Doorne go further by denoting that these entrepreneurs had social and cultural obligations, which more than often delimit the growth of their businesses. They are content with their ways of life. 
However, Shaw and Williams (2004) offer caution against such a notion. According to the authors, how these businesses are run varies according to the place and type of touristic activities. Based on a study of the surf tourism industry in Cornwall, they argue that although surf entrepreneurs are influenced by desires for freedom and being their own boss, and have interest in the environment, there is clear evidence that they, nonetheless also, have plans for business development and expansion, and are therefore profit oriented.

Meanwhile, sustainable tourism has taken the phrase alternative tourism, a generic term, to distinguish it from the conventional mass tourism (Butler, 1990; Weaver, 1991). Table 1 illustrates Weaver's notion of alternative forms of tourism, which among others have criteria that denote small-scale accommodation development, lower market volume and low import sector. Using Dominica as a case study, Weaver (1991) argues that tourism which started as a 'circumstantial' alternative tourism destination, conform to characteristics such as low visitation and impacts levels. Such a situation mirrors Butler's (1980) early stage of exploration and involvement. Dominica adopts a philosophical approach towards alternative tourism, using the Kastarlak Report (a United Nations' sponsored report on Dominica) as a blueprint to move forwards. This suggests among other things, specialised markets, such as environmentalists, as suitable for the country's tourism industry.

Alternative tourism as represented by many small companies emerges in the era of post-modernism to take advantage of the changing consumer trend, which demands more on special interest tours. From a wider perspective, there is a shift from Fordism, to a more flexible and small but specialised scale of modes of production and consumption (Harvey, 1990). However, scholars like Lickorish (1990) and Ritzer (1998) challenge this notion. Ritzer contends that even in specialised niche market like Starbucks, there tends to be a replication of mass production and consumption. Replication of a chain of Starbucks in other towns and countries mirrors the mass production of this branded product.

While many researchers have favoured alternative tourism development in place of mass form of tourism, work written by scholars on alternative development has wide range of issues. Some researchers like, Long and Wall (1995), Din (1997) and Dahles (2001) have explored the tourism entrepreneurship of indigenous population. Din (1997), for example, further argues that the lack of empowerment that has caused locals to be marginalized in Langkawi, Malaysia. (Note 8) Conversely the better equipped locals and outsiders are in the better position to reap the benefit. This gives rise to a question of empowerment in alternative tourism development.

In term of empowerment and the participation of the local community in sustainable tourism planning, there is some literature produced by researchers such as Murphy (1985), Gunn (1994) and Slinger (2000). Slinger, for example, shows that the indigenous Caribs (Note 9) have managed to revive their traditional crafts and culture which, earlier on, been subjected to a process of cultural erosion, encouraged by the government to participate in ecotourism activities. Furthermore, the Caribs have recognised the necessity of protecting the environment is important, particularly when they need raw materials from the forest to produce their handicrafts.

By using the empowerment issue in tourism development researchers such as Kinnaird and Hall (1994) and Apostolopoulos et al, (2001) have also further diverged into the new field of gender and tourism. Hitherto the history of tourism, which can be attributed by its birth from industrialisation and its transformation by post-industrialisation, has been mostly described from a 'masculine perspective' (Kinnard and Hall, 1994). Kothari (2002) contends that this view has been at the expense of other dimensions such as feminism. This is imperative given that tourism also takes into account the changing role of gender, such as the 'softening' of tourism attractions, activities, experiences and tastes. The stereotyping of this sexual imagery is further being enhanced by marketing brochures selling tourist destinations and products that use women as the pulling factor. While the male is associated with power and ownership the women are portrayed as passive and being owned (Edensor and Kothari, 1994). At the same time, this has produced a notion that tourism leads to prostitution (Mackie, 1988; Truong, 1990; Hall, 1994). A by-product of mass tourism, this particular form of activities is associated with male tourists who aim to travel to exotic places to indulge in sexual encounters with prostitutes either as a primary or a secondary agenda. Many scholars relate this phenomenon to developing countries. Hall (1994) on the other hand, argues that these activities also persist in developed countries even though it is more exploitative in the former. Conversely, sex-tourism has also evolved into the exploitation of male hosts by female tourists and also the emergence of the so-called gay tourist circuit. Gender relations in the tourism industry also transgress into the labour field. Bagguley (1990), for example, explores the relation of gender in tourism employment where a majority of part-time workers in the hotel industry are women. Nonetheless, Mowforth and Munt (2003) argue that although this new form of tourism has extensively influenced tourism activities in both developed and developing countries, it is arguably a western phenomenon. These authors argue that poor developing countries are still experiencing the effect of conventional mass tourists due to a major increase of such tourist groups from increasingly affluent middle class societies such as in Southeast Asia. However this trend is part of the evolutionary process that is happening in the region. 
Having said that, alternative tourism development unlike its predecessors provides not only a novel feature through its bottom-up process of advocating development but also incorporates a holistic notion of development process through its inclusion of indigenous or local participation in its framework.

\section{Conclusion}

This paper documented factors that underpinned tourism development theory, which are derived from the dominant theories of development; Modernisation, Dependency, Neo-liberalism and Alternative development. It also showed that development was progressive, as experienced in many countries. Development theory provides the suitable conceptual framework and platform to elucidate the processes in tourism development. It shows these processes are not solely the result of unilateral actions. Instead, the nature of tourism development is a highly contested one, which among others, is susceptible to influence from the surrounding milieu, invoked by factors such as politics, economics, culture and the environment. Such processes are made more complex by the fact that the tourism industry is composed of diverse inter-related fields, and as such are broad in scope and depth.

In sum, this paper provides the analytical framework whence strands in tourism development can be explored. It documents the links between development theory and the processes of tourism development, which are characterised by a complex nature of relationships between the four dominant paradigms of development theory and the nature of tourism development. This poses the question of the role of tourism in fulfilling the objectives of economic development.

\section{References}

Agarwal, S. (2002). Restructuring Seaside Tourism, the Resort Lifecycle. Annals of Tourism Research, 29(1), 25-55.

Apostolopoulos, Y., Sonmez, S. and Timothy, D. (2001). Women and Producers and Consumers in Developing Regions. Westport, Connecticut: Praeger.

Ateljevic, I. and Doorne, S. (2000). Staying Within the Fence: Lifestyle Entrepreneurship in Tourism. Journal of Sustainable Tourism, 8(5), pp378-92.

Bagguley, P. (1990). Gender and Labour Flexibility in Hotel and Catering. Service Industries Journal, 10(4), pp737-747.

Baidal, J. A. I. (2003). Regional Development Policies: An Assessment of their Evolution and Effects on the Spanish Tourist Model. Tourism Management, 24, pp655-663.

Baidal, J. A. I. (2004). Tourism Planning in Spain: Evolution and Perspective. Annals of Tourism Research, 31(2), pp313-333.

Boo, E. (1990). Ecotourism: The Potentials and Pitfalls. Vol. 1. Washington D. C: World Wildlife Fund.

Brenner, N. and Theodore, N. (2002). Preface: From the "New Localism" to the Spaces of Neoliberalism. Antipode, 34(3), pp341-347.

Britton, S. (1989). Tourism, Dependency and Development: A Mode of Analysis. In T. V. Singh, H. L. Theuns and F. M. Go (Eds.), Towards Appropriate Tourism: The Case of Developing Countries. (pp93-116). Frankfurt: Peter Long.

Britton, S. G. (1991). Tourism, Capital, and Place: Towards a Critical Geography of Tourism Development. Environment and Planning D: Society and Space, 9, pp451-78.

Brown, F. and Hall, D. (2000). Introduction: The Paradox of Peripherality. In F. Brown and D. Hall (Eds.), Tourism in Peripheral Areas: Case Studies (pp1-6). Clevedon: Channel View Publications.

Butler, R. (1980). The Concept of a Tourist Area Cycle of Evolution: Implications for Management of Resources. Canadian Geographers, 24, pp5-12.

Butler, R. (1990). Alternative Tourism; Pious Hope or Trojan Horse? Journal of Travel Research, 28, pp40-45.

Ceballos-Lascurain, H. (1987). Estudio de Prefactibilidad Socioeconomica del Turismo Ecologico y Anteproyecto Arquitectonio y Urbanistico del centro de Turismo Ecologico de Sian Ka'an, Quintana Roo. Mexico: study made for SEDUE.

Conference Report (1990). Theoretical Perspective on Alternative Forms of Tourism. Journal of Travel Research, 28(3), p39.

Crang, P. (1997). Performing the Tourist Product. In C. Rojek and J. Urry (Eds.), Touring Cultures: Transformation of Travel and Theory. (pp137-154). London: Routledge.

Dahles, H. (2001). Tourism, Heritage and National Culture in Java, Dilemmas of a Local Community. Surrey: Curzon.

Dann, G. M. S. and Cohen, E. (1991). Sociology and Tourism. Annals of Tourism Research, 18(1): pp155-169. 
de Kadt, E. (1979). Tourism - Passport to Development? Perspectives on the Social and Cultural Effects of Tourism in Developing Countries. Oxford: Oxford University Press.

Dernoi, L. A. (1981). Alternative Tourism: Towards a New Style in North-South Relations. International Journal of Travel Research, 2(December), pp253-264.

Desforges, L. (2000). State Tourism Institutions and Neo-liberal development: A Case Study of Peru. Tourism Geographies, 2(2), pp177-192.

Din, K. H. (1990). Bumiputra Entrepreneurship in the Penang-Langkawi Tourist Industry. Unpublished PhD dissertation, University of Hawaii.

Din, K. H. (1997). Tourism Development: Still in Search of a more Equitable Mode of Local Involvement. In C. Cooper and S. Wanhill (Eds.), Tourism Development, Environment and Community Issues. (pp153-162). West Sussex: John Wiley.

Edensor, T. and Kothari, U. (1994). The Masculinisation of Sterling's Heritage. In V. Kinnaird and D. Hall (Eds.) Tourism: A Gender Analysis. (pp164-185). Chichester: John Wiley and Sons.

Goeldner, C. R., Ritchie, J. R. and McIntosh, R. W. (2000). Tourism Principles, Practices, Philosophies. New York: John Wiley and Sons.

Gordon, C. (1991). Sustainable Leisure. Ecos, 12(1), pp7-13.

Gunn, C. A. (1994). Emergence of Effective Tourism Planning and Development. In A. V. Seaton (Ed.), Tourism: The State of the Art. (pp10-19). Chichester: John Wiley and Sons.

Hall, C. M. (1994). Gender and Economic Interests in Tourism Prostitution: The Nature, Development and Implications of Sex Tourism in South-East Asia. In V. Kinnard and D. Hall (Eds.), Tourism: A Gender Analysis. (pp142-63). Chichester: John Wiley and Sons.

Hall, C. M. (1998). Historical Antecedents of Sustainable Tourism Development: An Introduction. In C. M. Hall and A. Lew (Eds.), Sustainable Tourism: A geographical perspective. (pp1-12). Harlow: Longman.

Hall, C. M. and Page, S. J. (1999). The Geography of Tourism and Recreation: Environment, Place and Space. London: Routledge.

Harrison, D. (1995). International Tourism and the Less Developed Countries: A Background. In D. Harrison (Ed.), Tourism and the Less Developed Countries. (pp1-18). Chichester: John Wiley and Sons.

Harvey, D. (1990). The Condition of Post-modernity: An Inquiry into the Origins of Culture Change. Cambridge: Blackwell.

Hughes, G. (1992). Changing Approaches to Domestic Tourism. Tourism Management, 13(1), pp85-90.

Ioannides, D. (2001). Sustainable Development and Shifting Attitudes of Tourism Stakeholders: Toward a Dynamic Framework. In S. F. McCool and R. N. Moisey. Tourism, Recreation and Sustainability: Linking Culture and Environment. (pp55-76). Oxon: CABI Publishing.

Jafari, J. (1977). Editor's Page. Annals of Tourism Research, 5(sp. issue), pp6-11.

Jenkins, C. L. (1982). The Effects of Scale in Tourism Projects in Developing Countries. Annals of Tourism Research, 9(2): pp229-249.

Johnston, R. J. (1997). Geography and Geographer: Anglo-American Human Geography since 1945 (5 ${ }^{\text {th }}$ ed.). London: Wiley.

Kinnaird, V. and Hall, D. (1994). Tourism: A Gender Analysis. Chichester: John Wiley and Sons.

Komilis, P. (1994). Tourism and Sustainable Regional Development. In A. V. Seaton (Ed.), Tourism: The State of the Art. (pp65-73). Chichester: John Wiley and Sons.

Kothari, U. (2002). Feminist and Postcolonial Challenges to Development. In U. Kothari and M. Minogue (Eds.), Development Theory and Practice: Critical Perspectives. (pp35-51). Basingstoke: Palgrave.

Krippendorf, J. (1986). The New Tourist Turning Point for Travel and Leisure. Tourism Management, 7, pp131-35.

Lickorish, L. L. (1990). Tourism Facing Change. In M. Quest (Ed.), Howarth Book of Tourism. (pp108-127). London: Macmillan.

Long, V. H. and Wall, G. (1995). Small-scale Tourism Development in Bali. In M.V. Conlin and T. Baum (Eds.), Island Tourism: Management Principles and Practice. (pp237-57). Chichester: John Wiley and Sons.

Mackie, V. (1988). Division of Labour: Multinational Sex in Asia. In G. McCormack and Y. Sugimoto (Eds.), Modernisation and Beyond: The Japanese Trajectory. (pp218-232). Cambridge: Cambridge University Press. 
Maslow, A. H. (1987). Motivation and Personality (3 ${ }^{\text {rd }}$ ed.). New York: Harper Collins Publishers.

Mathieson, A. and Wall, G. (1982). Tourism: Economic, Physical and Social Impacts. London: Longman.

Mieczkowski, Z. (1981). Some Notes on the Geography of Tourism: A Comment. Canadian Geographer, 25, pp186-191.

Milne, S. and Ateljevic, I. (2001). Tourism, Economic Development and the Global-Local Nexus. Tourism Geographies, 3(4), pp369-393.

Miossec, J. M. (1976). Elements Pour une theorie de l'espace Touristique. Les Cahiers du Tourisme, C-36, Aix-en-Provence.

Mowforth, M. and Munt, I. (2003). Tourism and Sustainability: Development and New Tourism in the Third World $\left(2^{\text {nd }}\right.$ ed.). London: Routledge.

Murphy, P. E. (1985). Tourism: A Community Approach. London: Routledge.

Myrdal, G. (1957). Economic Theory and Under-developed Regions. London: Methuen \& Co.

Oppermann, M. and Chon, K. S. (1997). Tourism in Developing Countries. London: International Thomson Business Press.

Oppermann, M. (1992). Intranational Tourism Flows in Malaysia. Annals of Tourism Research, 19(3), $482-500$.

Oppermann, M. (1993). Tourism Space in Developing Countries. Annals of Tourism Research, 20(3), pp535-55.

Pearce, D. G. (1979). Towards a Geography of Tourism. Annals of Tourism Research, 6(3), pp245-272.

Pearce, D. G. (1989). Tourist Development (2 ${ }^{\text {nd }}$ ed.). New York: Longman.

Pearce, D. G. (1995). Tourism Today: A Geographical Analysis (2 ${ }^{\text {nd }}$ ed.). Harlow: Longman.

Pigram, J. J. (1985). Outdoor Recreation and Resource Management (2 ${ }^{\text {nd }}$ ed.). London: Croom Helm.

Poon, A. (1994). The New Tourism Revolution. Tourism Management, 15(2), pp91-95.

Ritzer, G. (1998). The Mcdonaldization Thesis: Explorations and Extensions. London: Sage.

Rostow, W. (1967). The Stages of Economic Growth. A Non-Communist Manifesto (2 ${ }^{\text {nd }}$ ed.). Cambridge: Cambridge University Press.

Scheyvens, R. and Momsen, J. H. (2008). Tourism and Poverty Reduction: Issues for small Island States. Tourism Geographies, 10(1), pp 22-41.

Schmidt, H. (1989). What Makes Development. Development and Cooperation, 6, pp19-26.

Shaw, G. and Williams, A. M. (1994). Critical Issues in Tourism: A Geographical Perspective. Oxford: Blackwell.

Sindiga, I. (1999). Tourism and African Development: Change and Challenge of Tourism in Kenya. Hampshire: Ashgate.

Slinger, V. (2000). Research Notes and Report on: Ecotourism in the Last Indigenous Caribbean Community. Annals of Tourism Research, 27(2), pp520-523.

Smith, S. L. J. (1988). Defining Tourism: A Supply-side View. Annals of Tourism Research, 15(2), pp179-190.

Smith, S. L. J. (1995). Tourism Analysis: A Handbook. (2 ${ }^{\text {nd }}$ ed.). Harlow: Longman.

Thurot, J. M. (1973). Le Tourisme Tropical Balneaire: le Modele Caraibe et ses Extensions, Thesis, Centre d'Etudes du Tourisme: Aix-en-Provence.

Truong, T. (1990). Sex, Money and Morality: Prostitution and Tourism in South-east Asia. (2 ${ }^{\text {nd }}$ ed.). London: Zed Books.

van Doorn, J. W. M. (1979). The Developing Countries: Are They Really Affected by Tourism? Some Critical Notes on Socio-cultural Impact Studies. Paper presented at Leisure Studies and Tourism Seminar, Warsaw.

Walpole, M. J. and Goodwin, H. J. (2000). Local Economic Impacts of Dragon Tourism in Indonesia. Annals of Tourism Research, 27(3), pp559-576.

Wang, N. (2000). Tourism and Modernity: A Sociological Analysis. Oxford: Pergamon

Weaver, D. B. (1991). Alternative to Mass Tourism in Dominica. Annals of Tourism Research, 18(3), pp414-432.

World Tourism Organisation (WTO). (1981). Tourism Multipliers Explained. Madrid: World Tourism Organisation and Horwarth and Horwarth. 


\section{Notes}

Note 1. Modernisation theory, has its early roots in growth theory, which is grounded in economics. Classical modernisation paradigm represents change as evolutionary processes, from a traditional agricultural rural-based to industry urban-based economy (Schmidt, 1989).

Note 2. Maslow explains the hierarchy needs of a human being based on the principle of relative potency. The hierarchy begins with physical needs, safety and security needs, social needs, ego needs and self-actualisation.

Note 3. This process can be inferred from growth type A of Butler's evolution of tourism development.

Note 4. European Economic Community.

Note 5. Spain became a member of the European Economic Community in 1986.

Note 6. Active travellers are those who visited more than four places and passive travellers are those who stayed at a maximum of four locations.

Note 7. The tour operator is the mediator between the consumers and the suppliers. Its main functions are primarily to reduce information and transaction costs to the consumer and to reduce promotional costs to the supplier. Its ability to make a huge volume of bookings of hotel rooms leaves little space for hotel operators to dictate the price, and as such it profits from the huge number of customers involved in its business transaction. Nonetheless, the huge number results in a lower price gained from the customers.

Note 8. Langkawi is an island resort in Malaysia. Its transformation from a forgotten Malay village to a holiday paradise has caused dramatic effects to the island's socio-culture and environment.

Note 9. Indigenous of Dominica.

Table 1. Characteristic Tendencies: Conventional Mass Tourism and Alternative Tourism

\begin{tabular}{|c|c|c|}
\hline Variable & Conventional Mass Tourism & Alternative Tourism \\
\hline \multicolumn{3}{|l|}{ Accommodations } \\
\hline Spatial pattern & Coastal, High density & Dispersed, Low density \\
\hline Scale & Larger-scale, Integrated & Small-scale, Homestyle \\
\hline Ownership & Foreign, Multi-national & Local, Family, Smallbusiness \\
\hline \multicolumn{3}{|l|}{ Market } \\
\hline Volume & Higher & Lower \\
\hline Origin & One dominant market & No dominant market \\
\hline Segment & Psychocentric-Midcentric & Allocentric-Midcentric \\
\hline Activities & Water/beach/night life & Nature/Culture \\
\hline Seasonality & Winter high season & No dominant season \\
\hline \multicolumn{3}{|l|}{ Economy } \\
\hline Status & Dominant sector & Supplementary sector \\
\hline Impact & High import sector & Low import sector \\
\hline & Repatriated profits & Retained profit \\
\hline
\end{tabular}

Weaver (1991) 


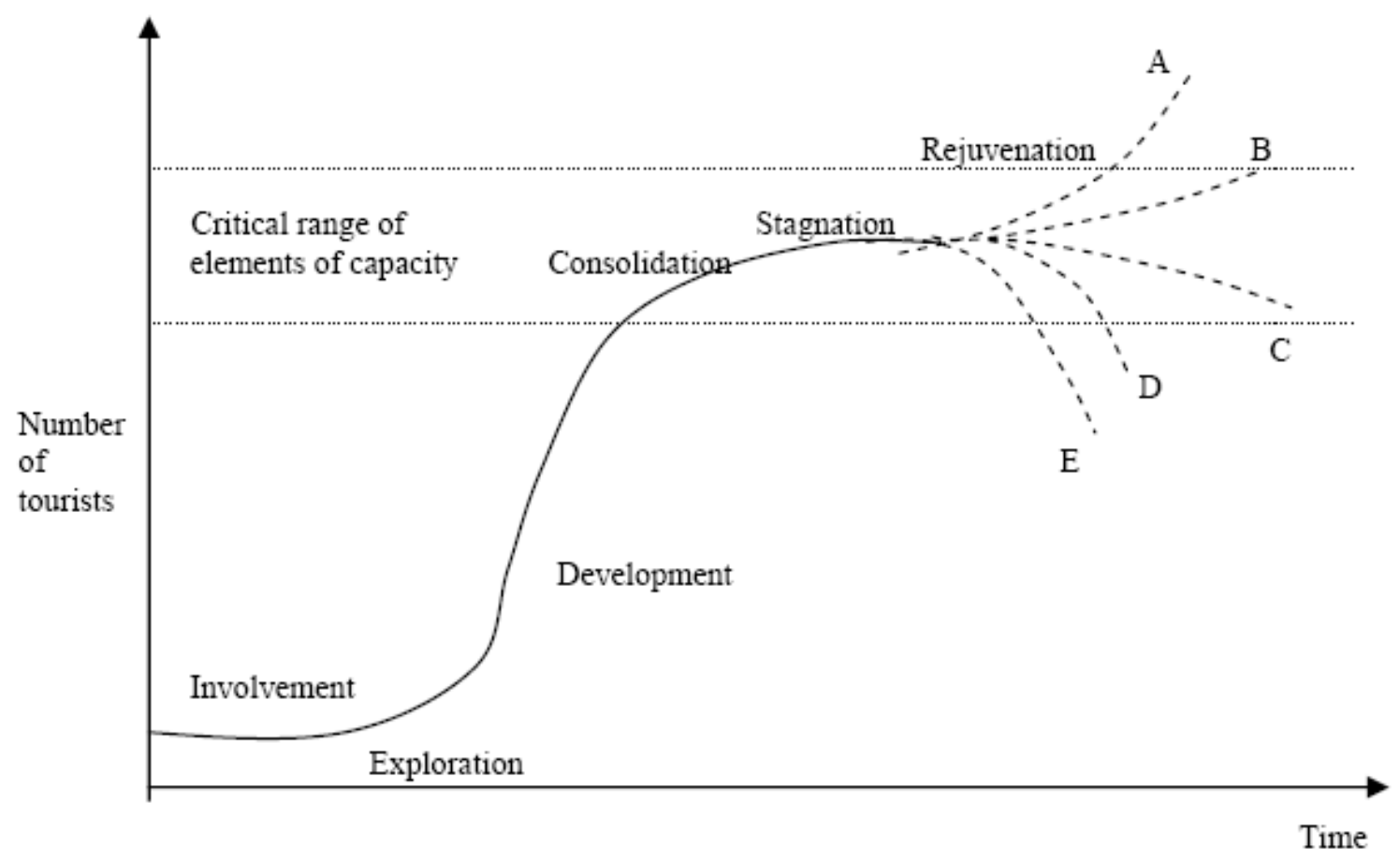

Figure 1. Butler's Destination Life-Cycle

A - Successful redevelopment leading to renewed growth and expansion.

B - Minor modifications which may include the protection of existing resources and price increases.

C - Some readjustment to meet existing demand which may include an increase in visitor prices to prevent further growth.

D - Over use of resources leading to destination decline largely as a result of competition with other areas.

E - War, politics or some other catastrophy halting tourism altogether.

Source: Butler, 1980. 